\title{
GODSDIENST, ZEDEN EN GEBRUIKEN DER BOSCHNEGERS
}

DOOR

L. JUNKER

I

Aangemoedigd door de gunstige beoordeeling welke mijne beide opstellen over de boschnegers „Eenige mededeelingen over de Saramaccaner-Boschnegers” en „Over de afstamming der boschnegers" mochten ontvangen, begon ik aan eene verhandeling over den godsdienst der boschnegers. Alras kwam ik echter tot de ontdekking dat deze materie niet zoo gemakkelijk te bewerken was; in de eerste plaats bleken mijne aanteekeningen te onvolledig en in de tweede plaats kon ik niet over betrouwbare literatuur beschikken. Zoo ik niet later het verwijt wilde hooren oppervlakkig te zijn geweest, moest ik eerst eene grondige studie van het te behandelen onderwerp maken en bij de boschnegers een nauwkeurig onderzoek instellen. Het laatste is het moeielijkste gedeelte van den voorbereidenden arbeid geweest.

Uit ervaring wist ik wel hoe men een boschneger aan het spreken kan krijgen, doch daar het thans alleen over dingen ging die de blanke niet behoeft te weten moest menige list worden gebruikt om het wantrouwen der negers te verschalken. Den gewonen weg, door vragen inlichtingen te verkrijgen, kan men bij de boschnegers niet volgen, omdat reeds door vragen omtrent de onschuldigste dingen, hun achterdocht wordt gaande gemaakt. Het beste is te doen voorkomen dat men alles reeds weet of door gebruik van magische kracht kan te weten komen. Gelukt het een boschneger onder dien indruk te krijgen 
dan is alles gewonnen. Onbewust verklapt hij de geheimen van den stam, want de godsdienst is het grootste geheim dat de boschneger kent.

Is een boschneger in gezelschap van anderen dan is het onnoodig een poging te doen om iets te weten te komen. Vermakelijk is het dan te zien hoe de boschnegers elkanders gevoelens toetsen en hoe angstvallig de antwoorden, vóór zij eruit komen, worden overwogen. Nog koddiger gaat het toe op een Kroetoe. Doordat bijv. in een geding alle getuigen gelijktijdig aanwezig zijn verklaren steeds de getuigen van eene partij hetzelfde. Geen gering opzien baarde het daarom toen ik op eene Kroetoe van de Kapiteins van de Gransaramacca, welke onder mijne leiding te Granmankondre gehouden werd, de getuigen liet opsluiten en een voor een op de vergadering deed verschijnen.

Gedurende mijne onderzoekingen betreffende den godsdienst der boschnegers schermde ik veel met de wetenschap vervat in het boekje van den posthouder bij de Aucaners, den heer Van Lier „Iets over de boschnegers aan de Boven Marowijne". Heel spoedig kwam ik tot de ontdekking dat in het hoofdstuk over godsdienst handelende vrij wat fantasie is ingeslopen en dat ook elders in het boekje in beschouwingen over den godsdienst pertinent gestelde beweringen worden geuit, die mij bij onderzoek gebleken zijn niet met de werkelijkheid der dingen overeen te komen. Het aardig samengestelde stelsel der hoogere goden ${ }^{1}$ ) bijv., dat door een met wat meer fantasie begaafden schrijver best tot de drieëenheid geconstrueerd zou kunnen worden, bestaat in het geheel niet.

Alvorens tot den eigenlijken godsdienst der boschnegers over te gaan zullen hier eenige beschouwingen op hun

1) „Dit opperwezen is de schepper van hemel en aarde en heerscher over alles en allen wat zich erop bevindt.

Nana staat evenwel zoover boven de stervelingen dat tusschengoden noodig zijn om hem te bereiken. Dezen zijn verdeeld in goden van hoogere en lagere orden, goede en booze. Onder die goden staat bij de Aucaners Gwangwella aan het hoofd en naast hem Gedéwsoe."

W. F. van Lier. Iets over de boschnegers aan de Boven Marowijne blz. 70.) 
plaats zijn. over het met geene tegenspraak rekening houdende beschouwingsleven van den boschneger en eenige woorden over fetíschisme van welk bovengenoemde schrijver beweert dat het bij de boschnegers niet bestaat ${ }^{1}$ ).

In de Kolonie noemt men de godsdienstuitingen der boschnegers (als zulke moeten zij zeker worden beschouwdaangezien door de aanwezigheid van een afhankelijkheidsgevoel van eene hoogere, bovenzinnelijke macht, dat bij alle verrichtingen op den voorgrond treedt, het godsdienstig karakter vrij duidelijk wordt bepaald) afgoderij ${ }^{2}$ ). Met dit woord neemt men min of meer lachend en veelal met geheime vrees kennis van het godsdienstige leven der boschnegers zonder zich de moeite te geven iets dieper in hun beschouwingsleven door te dringen en door dit aan kritiek te onderwerpen naar eene verklaring der godsdienstuitingen te zoeken.

De geheele, den boschneger omringende wereld is volgens zijne voorstelling door geesten bewoond. Dezen hebben hunne huisvesting genomen in de aarde, het water, de lucht, het bosch, de enkele boomen, in steenen, kortweg overal. Buitendien stelt men zich voor dat geesten of geestenmacht in daartoe vervaardigde voorwerpen kunnen wonen resp. in deze gebracht kunnen worden of dat bijzondere voorwerpen magische kracht (zielestof?) uit zich zelve bezitten. Het vorenstaande vertoont ons duidelijk het beeld van een verward weefsel der drie godsdienst-

1) Zijn (de Djoekas) orakel „Grantata” genaamd is dan ook een verzameling van reliquieën, zooals hoofdhaar, nagels, stukjes met bloed bevlekte kleeren van in den strijd gevallen helden, enz.

Van de verschillende geesten, die Grantata uitmaken, worden door hen persoonsvoorstellingen gemaakt, aan wie ze op geregelde tijden offeren, te eten en te drinken geven.

(W. F. van Lier, blz. 12) en verder op blz. 28:

Door allen die over hen (de boschnegers) geschreven hebben is tot dusver gezegd dat zij aan fetischen dienst doen. Ik beweer dat die meening onjuist is. Dat de schrijvers dien indruk kregen, is naar mijn oordeel een gevolg van te vluchtige aanraking met de boschnegers. Een boschneger doet niet aan fetischen dienst. Integendeel, zijn goden zijn onzichtbare wezens. $\mathrm{Zij}$ hangen wel het veelgodendom aan, enz.

$\left.{ }^{2}\right)$ Deze uitdrukking wordt ook algemeen gebezigd voor het in de Kolonie veel heerschende bijgeloof en den daarmede verband houdenden hokus pokus van bezweringen van geesten, ziekenbehandelingen, enz. 
richtingen van den natuurmensch het spiritisme, fetischisme en animisme.

Bovendien is in dit donkere weefsel nog een heldere draad van een monotheïsme ingeweven, hetgeen zooals wij later zullen zien reeds in Afrika moet geschied zijn.

Ofschoon het christendom en het jodendom er eenige gekleurde draden doorheen hebben getrokken is daardoor niets van zijn somber aanzien veranderd.

Het zijn vooral de geesten waarvan zich de boschneger afhankelijk weet; met hen heeft hij zijn geheele leven te doen. Ieder voorval, ook zulke welke voor een gewoon mensch niet van de minste beteekenis zijn, wordt in verband gebracht met den invloed welke geesten, en menschen die macht over geesten bezitten, op hem uitoefenen. Doordat hij aan zijne voorstellingen en ook aan zijne droomen volkomen waarheid toekent is hij in een voortdurenden strijd gewikkeld met geesten en menschen, is hij voortdurend bezig middelen te beramen en te beproeven welke tot verweer moeten dienen. Dat kost tijd en geld en oefent natuurlijk een zeer nadeeligen invloed uit op het geheele sociale leven der boschnegers. In de eerste plaats moet de familie eronder lijden. Haar hoofd heeft door het verrichten van zijne, ,godsdienstige" bezigheden den tijd voorbij laten gaan die gunstig was voor het aanleggen der kostgronden. Soms gebeurt het dat geheele onderstammen eene foeka ${ }^{1}$ ) hebben en dat wekenlang godsdienstverrichtingen plaats hebben waarvan het gevolg is dat er het volgende jaar gebrek aan voedingsstoffen ontstaat. De uit zulke voorstellingen geboren zeden en gewoonten werken belemmerend op vooruitgang en ontwikkeling en zelfs de christenboschnegers kunnen zich daarvan niet vrij maken, zooals uit het volgende staaltje blijkt.

In het jaar 1917 op het christendorp Ganzee vertoevende was ik getuige dat aldaar de bewoners van het heidensche dorp Kadjoe aankwamen teneinde een zoogenaamde

1) foeka = nood, hinder, ramp.

Het gevoel van nood is in 't algemeen bij den neger sterk ontwikkeld en speelt in het bijgeloovige leven in de Kolonie een groote rol. 
sibi $\left.^{1}\right)$ te houden. De aanleiding tot deze raid was daarin gelegen dat eene vrouw van Ganzee beschuldigd werd eenen man van Kadjoe vermoord te hebben. De doode had haar als moordenares aangewezen en daarmede was het bewijs geleverd. Aanvankelijk ontkende de vrouw, doch later herinnerde zij zich den man, met wien zij vroeger samengeleefd had, eens iets ingegeven te hebben, teneinde zich door het hier gebruikte middel de echtelijke trouw van den man te verzekeren.

De bewoners van Kadjoe eischten onder de bedreiging geweld te zullen gebruiken een groot aantal dingen als rijst, olie, rum, enz. op. Hetgeen de familie der beschuldigde vrouw tehuis had werd afgegeven. Niemand van de overige bewoners van het zeer groote dorp kwam in verzet, integendeel, men erkende dat de familie van den vermoorden man in haar volste recht was. Omdat alle geeischte goederen niet bij de hand waren werd uitstel voor de levering verleend, echter onder de bedreiging, dat zoolang de levering niet geschied was niemand van de leden der familie waartoe de vrouw behoorde, naar het bosch of de kostgronden mocht gaan, daar overtreders van het verbod onvoorwaardelijk met ziekte en dood zoude worden gestraft. Zooals mij de schoolmeester van Ganzee later mededeelde heeft niemand gewaagd het verbod te overtreden en werd al het geëischte aan de familie van den vermoorden man geleverd.

Het zal den lezer zeker nog belang inboezemen dat kortgeleden de uitspraak van den doode door de geesten werd bevestigd. September 1922 werd de van moord be-

\footnotetext{
1) $\mathrm{sibi}=$ bezem.

Onder de handeling hierboven beschreven wordt begrepen het met geweld invorderen van vergoeding voor toegebrachte schade. Het gebeurt soms dat inderdaad tot geweld wordt overgegaan. In het jaar 1920 kostte het mij alle moeite de bewoners van het dorpje Ganinakondoe, (de familie van een vermoorden boschneger) tegen te houden den oudsten broeder van den moordenaar, die naar boschnegerbegrippen nog al rijk was, op het dorp Baaikoetoe met een sibi te vereeren. -

De toegebrachte schade kan van velerlei aard zijn wanneer slechts naar de opvatting van den boschneger de geheele familie getroffen wordt, in welk geval ook weder de familie van den beschuldigde verantwoordelijk wordt gesteld voor de overtreding van een harer leden. (defloratie, moord).
} 
schuldigde vrouw door een vallenden boom doodelijk getroffen.

Door het boven gezegde over de uitspraak van den doode maken wij kennis met een anderen trek uit het beschouwingsleven van den boschneger. Ziel en lichaam zijn voor hem een en hetzelfde begrip, hij kan zich de beiden niet afgescheiden van elkaar voorstellen. Het lichaam gaat wel tot bederf over doch de ziel verlaat het niet, en deze laatste zet haar materieel bestaan voort ook wanneer het lichaam niet meer voorhanden is ${ }^{1}$ ). Zij blijft op aarde rondwandelen, komt nog eten, en geeft aan de achtergeblevenen raad. Het lijk wordt daarom lang boven den grond gehouden in het bijzonder wanneer de overledene een man van groote geestvermogens is geweest. Zoo werd het lijk van het grootopperhoofd Oesesi drie maanden lang boven een vuurtje geroosterd, alvorens hij begraven werd omdat men telkens nog om zijnen raad verlegen was.

Van belang is het nog de verwarring op spiritistisch gebied heerschende vast te stellen. Van sommigen had ik vernomen dat de afgestorvene naar een bijzondere plaats verhuist, zoodra de, hem kort na overlijden afgesneden hoofdhaaren begraven worden. Dit gebeurt ongeveer drie maanden na het overlijden. Anderen beweerden dat de jorkas altijd op aarde bleven. Weder anderen vertelden dat de dooden naar het Opperwezen gingen. Te Goddo was ik eens tegenwoordig toen, na den afscheidsmaaltijd voor een ongeveer drie maanden geleden overleden boschneger een man de kleine trom, Apintigenaamd,

$\left.{ }^{1}\right)$ Mij aan den Granrio ophoudende kwamen eenige bewoners van het dorp Toemaripa bij mij en vertelden mij dat de jorka van een franschman op het dorp reeds drie vrouwen had gedood. Uit de verdere mededeelingen vernam ik het volgende: Een bewoner van het dorp had op de vrachtvaart op de Marowijne zijnde in de rivier het lijk van eenen déporté gevonden. Hij nam het hoofd van den doode mede naar huis om daaruit een toovermiddel (obia) te maken. De den schedel nog bewonende geest, (jorka) als die van een franschman van zeer kwaadaardigen aard zijnde, had de daden van den levenden deporté voortgezet en was thans bezig de vrouwen van het dorp uit te moorden. Ik gaf den raad den schedel in den Biabie, een gevreesden waterval, te werpen. Dit werd gedaan en later stierven toevallig ook geene vrouwen meer. 
op zeer eigenaardige wijze sloeg. Op de vraag wat hij voor seinen gaf kreeg ik het volgende verhaal te hooren. De man (doode) is thans op weg naar Grangado. De weg daarheen is zeer moeilijk en heeft vele zijwegen die naar het rijk van didibri ${ }^{1}$ ) leiden. Aan mijnen vriend Grandompie, het dorpshoofd van Goddo, vroeg ik omtrent de reis van zijn overleden familielid om inlichtingen. Ik vernam toen dat zoolang de jorka op den goeden weg bleef hij ook de trom kon hooren en de aanwijzingen door deze gegeven kon opvolgen. Hij moest dus goed opletten en zoude dan ook zeker de plaats bereiken waar alle goede afgestorvenen der Saramaccaners bij elkaar verzameld waren.

Omtrent de aanwijzingen van den weg die toch nooit door een der achtergeblevenen beloopen was geworden wilde Grandompie zich niet uitlaten. Ook toen ik hem er opmerkzaam op maakte dat hij mij kortgeleden had verteld dat de Grangado zich het lot der menschen hoegenaamd niet meer aantrok kreeg ik ten antwoord: „Dat kan zijn, doch de dooden gaan naar de plaats die hij (Grangado) voor de jorkas heeft aangewezen. Zoo heb ik het altijd gehoord". Geen jorka komt echter in aanraking met het Opperwezen.

Van een anderen ouden boschneger hoordeik dat booze menschen en ook op gewelddadige wijze om het leven gekomen personen altijd op aarde moesten blijven ronddwalen.

Dit houdt zeker verband met de opvatting dat zulke menschen door een geest en dan meestal ter vergelding voor bedreven kwaad worden gedood.

Ook vernam ik van dezen boschneger dat er wel degelijk een duivel bestond, doch dat deze geen macht over de levenden had en ook aan de booze geesten geen opdrachten verstrekt om de menschen te kwellen. Het is dan met den booze bij de boschnegers zooals met het Opperwezen gesteld. Beiden hebben zich uit de wereld teruggetrokken, de menschen overlatende aan de geesten.

Niet onmogelijk is het dat het begrip van den duivel op christelijke invloeden teruggebracht kan worden. Het be-

1) didibri = duivel. 
grip van het opperwezen (als begrip bestaat slechts de Grangado zooals we later zullen zien), moet echter van afrikaanschen oorsprong zijn.

In tegenstelling van den heer van Lier beweer ik dat de boschnegers op zeer uitgebreide schaal aan fetischen dienst doen.

Ik meen te mogen zeggen dat het gestelde op blz. 12 in meer genoemd boekje van den heer van Lier, aangaande den Grantata, de beschrijving van een fetisch in optima forma is. Hij heeft door de beschrijving van den Grantata duidelijk bewezen dat de boschnegers aan fetischen dienst doen.

De lezer lette nog bijzonder op de bestanddeelen van den grantata; het zijn alles voorwerpen waarvan de natuurmensch veronderstelt dat er eene groote magische kracht van uitgaat. Zoodoende zijn wij aan de grens van Spiritisme en Animisme gekomen.

De voorwerpen welke door hun uiterlijk of vorm door de busclunegers geacht wordon magischo leracht (dus in hooge mate zielestof) te bezitten zijn niet talrijk, zoodat natuurlijk van een zuiver uitgesproken Animisme geene sprake is. Bijzonder magische kracht gaat uit van pimba en van aarde in het algemeen. Ook de steenen bijlen der vroegere Indianen welke aan de Boven-Suriname en de Tapanahony worden gevonden staan hoog in aanzien. Men veronderstelt dat dezen gedurende onweersbuien uit den hemel op de aarde vallen en noemt ze daarom dondroeston (dondersteen). Schelpen worden eveneens verondersteld magische kracht te bezitten. Het is best mogelijk dat eenige stammen waarvan de boschnegers afstammen meer animistisch gedacht hebben. Waar zich echter in Afrika bij de aldaar achtergebleven stammen uit het animisme geen hoogere godsdienst kon ontwikkelen, integendeel het fetichisme meer en meer grond gewonnen heeft, is het licht begrijpelijk dat bij de boschnegers in Suriname, het mengsel van vele volkstammen der Westkust van Afrika, geen godsdienst van zulke eenheid, zooals deze in het boekje „Iets over de boschnegers aan de Boven Marowijne" wordt beschreven, kon ontstaan. 
Stedman noemt in zijn boek ,Narrative of an Expidition to Surinam" op blz. 207 onder bijvoeging van etc. veertien stammen waarvan de ingevoerde slaven afkomstig waren. De woonplaatsen dezer stammen hebben gelegen of liggen nog heden in het onmetelijk gebied langs het geheele Westen van Afrika. In dit reusachtige gebied wonen honderde stammen, die er duizende, van elkaar verschillende godsdienstopvattingen op na houden.

Men kan dus gerust aannemen dat in Suriname honderde voorstellingen van godsdienstig karakter werden ingevoerd en dat dezen heden ten dage nog talrijk zijn, zullen we later zien. Enkele dezer hebben algemeene beteekenis voor alle boschnegers of voor enkele stammen verkregen; geen hunner domineert echter dermate dat men van eenen algemeenen godsdienst spreken kan.

Naarmate een fetischpriester meer of minder invloed uitoefende of een voorstelling meer of min door het algemeen ontwikkelde gevoel van nood, bijv. de onderwerping door de blanken, opgedrongen was geworden, verkreeg een voorstelling ook meer of minder recht van bestaan.

De werkelijke en denkbeeldige nooden van den boschneger zijn talrijk, hij is daarom voortdurend zoekende naar hulp en maakt zich voortdurend nieuwe voorstellingen. Dat deze meestal met elkaar in tegenspraak zijn daar mede houdt hij geene rekening. Door deze wijze van denken krijgen zijne zeden en gebruiken soms eene geheel andere beteekenis en is het voor den onderzoeker in de eerste plaats noodzakelijk met dit primitieve denken bekend te worden.

(Wordt vervolgd). 